\title{
線状補強材の強度異方性を考慮した 混合型剛塑性有限要素法の開発
}

\author{
山栗 祐樹 1 - 小林 俊一 $2 \cdot$ 西藤 $\quad$ 潤 $3 \cdot$ 松本 樹典 4 \\ 1学生会員 金沢大学大学院 自然科学研究科環境デザイン学専攻（† 920-1192 石川県金沢市角間町） \\ E-mail: kuriyama3318@gmail.com \\ 2 正会員 博士（工） 金沢大学准教授理工研究域地球社会基盤学系（ $\bar{T}$ 920-1192 石川県金沢市角間町） \\ E-mail:koba@se.kanazawa-u.ac.jp \\ 3 正会員 博士（工）京都大学大学院准教授 工学研究科 社会基盤工学専攻（ $\bar{T}$ 606-8501 京都市西京区京都大学桂 C-1） \\ E-mail: saito.jun.3n@kyoto-u.ac.jp \\ 4 正会員 工博 金沢大学教授 理工研究域地球社会基盤学系（ ( 920-1192 石川県金沢市角間町） \\ E-mail: matsumoto@se.kanazawa-u.ac.jp
}

支持力問題の破壊時のモードと終局限界荷重を直接解く数值解析法の 1 つに極限定理に基づく剛塑性有限要 素法がある. 剛塑性有限要素法で線状補強材による補強地盤を取り扱う際, 既往研究では 2 節点間の距離不変 条件を課したモデル化が提案されているが, 本研究では極限解析法の双対性に着目し, 下界法から 2 節点間の 距離不変条件を再検討した. 2 節点間の距離不変条件に対応するラグランジュ乗数は, 2 節点間に働く拘束力と 解釈でき，さらに拘束力が無制約であれば補強材強度が十分大きいとみなせる．そこで，本論文では下界法に 基づく剛塑性有限要素法に拘束力に関する制約条件を追加することにより，線状補強材の強度特性も考慮した 一般的な状況に対する定式化を示した。ささらに数值実験例を示し，提案手法の有効性を示した。

Key Words: rigid plastic finite element method, soil reinforcement, anisotropic strength, duality

\section{1. はじめに}

土質力学の古典的な問題，支持力問題や斜面の安定 問題，土圧問題のような剛塑性解析に有限要素による 空間離散化を組み込み, 非線形最適化問題として定式 化した数值解析法が剛塑性有限要素法である.

剛塑性有限要素法は極限定理に基づいて定式化が行 われる. Tamura et al. ${ }^{1), 2)}$ は上界法に基づいて定式化を 行い, 地盤安定問題への有効性を示した。一方，下界法 に基づいて剛塑性有限要素法を定式化することも可能 である．また，上界法と下界法は互いに双対関係（極限 定理の双対性）にある。著者らはこの双対関係に着目 して，下界法に基づくラグランジュ関数を導入し， ラ グランジュ双対性を利用して, 最適解を与える最適性 条件（=Karush-Kuhn-Tucker(KKT) 条件）を解く手法を 提案してきた。導出過程において双対問題である上界 法の制約条件も導出されるため, KKT 条件を解くこの 手法は混合型剛塑性有限要素法3),4),5),6),7) と呼ばれる.

剛塑性有限要素法は無補強の土構造物だけではなく, ジオテキスタイルやアンカー材によって補強された補 強土構造物への安定解析にも適用することができる.上 界法に基づく剛塑性有限要素法の枠組みで, Asaoka et al. ${ }^{8)}$ は地盤補強材をモデル化する方法として, ジオテキ スタイルのような補強材と接する土要素の長さは不変と
考え, 節点間の距離不変条件を提案した。また Kodaka et al. ${ }^{9)}$ は補強土壁のパネルや吹付コンクリートのよう な補強工法については, 補強材と接する土要素の角度 は不変と考え, 3 点間が直線上に位置する条件（曲がら ない条件）を提案した。これらの共通点は, 節点変位 速度場に等式制約条件を付加することである.

これを極限定理の双対性の観点から下界法として解 釈すると, 補強材の強度が引張 ·圧縮側ともに十分に 大きいことを意味する（2. (4) で議論する）。一方, 現 実の補強材の強度は有限であり, 強度の上限・下限の制 約を受ける不等式制約条件として表現できる。またジ オテキスタイルのように, 引張には抵抗するが圧縮に はほとんど抵抗しない等, 異方的な強度を有する補強 材もある。このような不等式制約を考慮した剛塑性有 限要素法を実装するためには, いったん双対問題であ る下界法を考えた方が理論的に明快である.

そこで本論文では，ジオテキスタイルのように異方 性の強度を有する補強材によって補強された土構造物 の安定性を評価することを念頭に，上界法で提案され た補強材のモデル化を拡張する方法を提案する。具体 的には, 下界法に基づく剛塑性有限要素法の定式化を 行い，新たに補強材による地盤拘束力に不等式制約条 件を付加する方法を提案する.

上界法と下界法が互いに双対関係にあることを考慮 


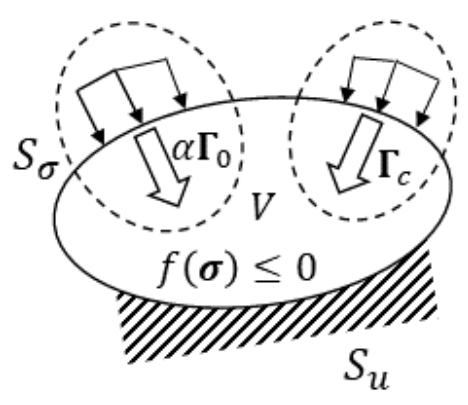

図-1 対象とする剛塑性境界值問題

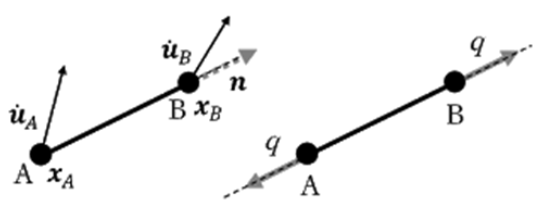

図-2 距離不変条件

して, 上界法で提案された補強材のモデル化を再検討 することは本研究の着眼点である. また, 異方的な強 度を有する補強材をモデル化するために, 補強材強度 に不等式制約を付加した定式化は著者らが知る限り見 当たらない。

さらに本論文では, 補強土地盤上の浅い基礎の支持 力解析を例に簡単な数值実験を行い, 提案手法を検証 した結果について報告する。

\section{2. 地盤補強材の強度特性を考慮した剛塑性 有限要素法の定式化}

\section{(1) 問題の設定}

本研究で対象とする剛塑性境界值問題を図-1に示す. 解析対象領域が $V$ である物体は剛完全塑性体と仮定す る. 応力境界（ノイマン条件）には荷重係数 $\alpha$ に比例 した荷重べクトル $\alpha \boldsymbol{\Gamma}_{0}$ が, 物体の領域および応力境界 には一定荷重べクトル $\boldsymbol{\Gamma}_{c}$ が作用する。変位速度境界 （ディリクレ境界条件） $S_{u}$ では変位速度ゼロの斉次ディ リクレ境界条件を仮定する，本論文では，対象とする 物体が塑性崩壊するときの荷重係数 $\alpha$ を最適化問題に よって評価する.

\section{（2）下界法に基づく定式化}

剛塑性境界值問題を解くため, 極限定理に基づく下 界法（静力学的方法）によって定式化を行う. 下界法と は応力場を未知量とし, 力の釣合い式と降伏条件を満 足するように荷重係数が最大となる応力場を求める方 法である，すなわち，力の釣合い式と降伏条件を制約 条件として荷重係数 $\alpha$ を最大化する非線形最適化問題
として記述することができる，さらに本論文では, 地 盤補強材の強度特性を考慮し, 新たに補強材による地 盤拘束力 $\boldsymbol{q}_{r}$ に対して不等式制約条件を付加した.

距離不変条件の概念図を図-2 に示す. 幾何非線形性を 無視して $\mathrm{AB}$ 間の距離不変条件を線形近似すれば， $\mathrm{AB}$ 間の伸び速度がゼロとなる条件が導出できる. $\mathrm{AB}$ 間の 伸び速度は引張りを正とすると

$$
\dot{\delta}=\left(\dot{\boldsymbol{u}}_{B}-\dot{\boldsymbol{u}}_{A}\right) \cdot \boldsymbol{n}
$$

である。ここに， $\dot{\boldsymbol{u}}_{A}, \dot{\boldsymbol{u}}_{B}$ は節点の変位速度ベクトル， $n$ は A から B への単位ベクトルである.したがって, 距離不変条件は以下で近似できる.

$$
\left(\begin{array}{llllll}
n_{1} & n_{2} & n_{3} & -n_{1} & -n_{2} & -n_{3}
\end{array}\right)\left\{\begin{array}{l}
\dot{u}_{B 1} \\
\dot{u}_{B 2} \\
\dot{u}_{B 3} \\
\dot{u}_{A 1} \\
\dot{u}_{A 2} \\
\dot{u}_{A 3}
\end{array}\right\}=0
$$

課される全ての距離不変条件をまとめると, 以下の形 で表現できる.

$$
\left[\boldsymbol{D}_{r}\right]\left\{\dot{\boldsymbol{u}}_{N}\right\}=\{\mathbf{0}\}
$$

ここに, $\boldsymbol{D}_{r}$ は距離不変条件に関する行列であり, $\dot{\boldsymbol{u}}_{N}$ は全ての節点変位速度場をまとめたべクトルである.

2 点間の変形が拘束されることは，それを生じさせる ための拘束力が作用することを意味する。 そこで, 距 離不変条件の意味を釣り合いの立場で考える。 AB 間 に働く拘束力（引張が正）を $q$ とおき，これを節点荷 重に書き直すと，

$$
\left\{\begin{array}{l}
f_{A 1} \\
f_{A 2} \\
f_{A 3} \\
f_{B 1} \\
f_{B 2} \\
f_{B 3}
\end{array}\right\}=\left\{\begin{array}{c}
n_{1} \\
n_{2} \\
n_{3} \\
-n_{1} \\
-n_{2} \\
-n_{3}
\end{array}\right\} q
$$

となる. 全ての距離不変条件についてまとめると, 以 下の形を得る.

$$
\left[\boldsymbol{D}_{r}\right]^{T}\left\{\boldsymbol{q}_{r}\right\}=\left\{\boldsymbol{f}_{r}\right\}
$$

ここにベクトル $\boldsymbol{q}_{r}$ はそれぞれの距離不変条件に関する 拘束力をまとめて表記したベクトル， またベクトル $\boldsymbol{f}_{r}$ はこれらの拘束力に起因する全ての節点変位荷重をま とめたベクトルである.

この拘束力 $q$ が無制約であることは, 強度が十分に 大きな補強材のために $\mathrm{AB}$ 間の距離が変化できない, と みなせる．このような距離不変条件を「完全拘束条件」 と呼ぶことにする。一方, 実際には補強材強度は有限 である，そこで拘束力 $q$ について, 補強材強度を反映 した不等式制約条件を課すことで, 補強材強度も考慮 
した補強土地盤の剛塑性モデル化が可能である。また， 従来の完全拘束条件では, 引張り側にも圧縮側にも十 分に大きな強度を有する (1 次元の意味で) 等方的な補 強材しか扱えないが，拘束力に不等式制約条件を課す ことで， 線状補強材のように圧縮側と引張り側で強度 特性が異なる異方的な補強材をモデル化することも可 能となる. なお既往研究において, 拘束力に不等式制 約を課した定式化はなされていない.

領域内での空間離散化した力の釣合い式の弱形式は 形式的に次式で表される.

$$
\boldsymbol{B}^{T} \boldsymbol{\sigma}=\alpha \boldsymbol{\Gamma}_{0}+\boldsymbol{\Gamma}_{c}+\boldsymbol{D}_{d}^{T} \boldsymbol{p}+\boldsymbol{D}_{r}^{T} \boldsymbol{q}_{r}
$$

ここに, $B$ は有限要素による空間離散化および数值 積分による領域積分を考慮した B マトリクスであり， $\sigma$ は応力評価点における応力を並べた応力べクトルであ る.これらの具体的な表記は 2.(6) で述べる. $D_{d}$ はディ リクレ境界条件に関する行列であり, スライダー支点や 固定支点を指定する節点に対応するように成分を与え る. $\boldsymbol{p}$ はディリクレ境界上の反力である. $\boldsymbol{D}_{r}$ は距離不 変条件に関する行列であり, その成分は Asaoka et al. ${ }^{8)}$ に倣って記述する． $\boldsymbol{q}_{r}$ は地盤が受ける地盤補強材によ る拘束力（以後, 地盤拘束力と称す.) である.

塑性学的に許容な応力場であるためには応力が降伏条 件を満足する必要があり, その条件が次式で表される.

$$
f_{i}\left(\boldsymbol{\sigma}_{i}\right) \leq 0, \quad \forall i
$$

ここに, $f_{i}$ は降伏関数である. なお, 下添字 $i$ は応力 評価点に対応する.

さらに，たとえば地盤拘束力に非負条件 $\boldsymbol{q}_{r} \geq \mathbf{0}$ を課 せば 2 点間距離が縮むことはないが伸びても構わない という条件となる。これを本論文では「不完全な拘束」 と呼ぶ．拘束力に制約条件を付加すると不完全拘束に なることは後述するように, 拘束力も含めた釣合い式 および拘束力に関する制約条件を課した下界法に基づ くラグランジアンを定義し, その双対性を利用して導 出できる 2 点間の伸び速度に関する制約条件から説明 できる.

より一般的には， $\boldsymbol{q}_{r}$ の制約条件を $h_{j}\left(q_{r}^{j}\right) \leq 0$ のよう な形式で表せばよい. したがって, 地盤拘束力の取り 得る範囲を指定する条件は次式で表される.

$$
h_{j}\left(q_{r}^{j}\right) \leq 0, \quad \forall j
$$

関数 $h_{j}\left(q_{r}^{j}\right)$ については後述する. なお, 添字 $j$ は距離 制約条件に対応する.

まとめると, 地盤補強材の強度異方性を考慮した下 界法は式 (6) から (8) を制約条件とした, 荷重係数 $\alpha$ を


図-3 地盤拘束力に関する不等式制約条件

最大化する非線形最適化問題として表される.

$$
\begin{aligned}
& \text { Find } \underset{\boldsymbol{\sigma}, \alpha, \boldsymbol{p}, \boldsymbol{q}_{r}}{\max } \alpha \\
& \text { s.t. }\left\{\begin{array}{l}
\boldsymbol{B}^{T} \boldsymbol{\sigma}=\alpha \boldsymbol{\Gamma}_{0}+\boldsymbol{\Gamma}_{c}+\boldsymbol{D}_{d}^{T} \boldsymbol{p}+\boldsymbol{D}_{r}^{T} \boldsymbol{q}_{r} \\
f_{i}\left(\boldsymbol{\sigma}_{i}\right) \leq 0, \quad \forall i \\
h_{j}\left(q_{r}^{j}\right) \leq 0, \quad \forall j
\end{array}\right.
\end{aligned}
$$

（3）異方強度特性を有する地盤補強材に対応した不等 式制約条件の表現法について

凸関数の関数 $h_{j}\left(q_{r}^{j}\right)$ は地盤拘束力 $q_{r}^{j}$ に対する非線形 制約条件である。例えば，両側不等式制約

$$
q_{\min }^{j} \leq q_{r}^{j} \leq q_{\max }^{j}, \quad \forall j
$$

を表現する最も簡単な凸関数は図-3に示すとおりであ り,

$$
h_{j}\left(q_{r}^{j}\right)=\left(q_{r}^{j}-q_{\min }\right)\left(q_{r}^{j}-q_{\max }\right)
$$

と記述できる.

この凸関数を導入することで $h_{j}<0:$ 剛体, $h_{j}=0:$ 塑性を判定することができる.したがって, 式 (8) は地 盤補強材に関する降伏条件と見なすことができる.

また凸関数を導入する利点として, ディリクレ境界 条件と距離不変条件を 1 つの不等式制約条件として扱 うことが可能となることが挙げられる。これはディリ クレ境界条件に関する行列 $D_{d}$ と距離不変条件に関す る行列 $\boldsymbol{D}_{r}$ を 1 つの行列 $\left(\boldsymbol{D}=\left[\begin{array}{ll}\boldsymbol{D}_{d} & \boldsymbol{D}_{r}\end{array}\right]^{T}\right)$ に格納し， ディリクレ反力 $\boldsymbol{p}$ も地盤の変形を拘束する力と考え, 全 ての変形を拘束する力に対して両側不等式制約条件を 与える.このように考えることでディリクレ境界条件 と距離不変条件をまとめて 1 つの不等式制約条件とし て記述することができる. なお，本論文では先に示し たようにディリクレ境界条件と距離不変条件に関する 項を分けて記述する. 


\section{（4）最適性条件と補強材の取り得る状態に関する考察}

式 (9) の最適解を与える最適性条件（KKT 条件）は, 式 (9) に対するラグランジュ関数を導入し， ラグラン ジュ双対性から導出できる. ラグランジュ関数は次式 で表される.

$$
\begin{array}{r}
L=\alpha+\boldsymbol{\mu} \cdot\left(\boldsymbol{B}^{T} \boldsymbol{\sigma}-\alpha \boldsymbol{\Gamma}_{0}-\boldsymbol{\Gamma}_{c}-\boldsymbol{D}_{d}^{T} \boldsymbol{p}-\boldsymbol{D}_{r}^{T} \boldsymbol{q}_{r}\right) \\
-\sum_{i=1}^{n} \lambda_{i} f_{i}\left(\boldsymbol{\sigma}_{i}\right)-\sum_{j=1}^{m} \omega_{j} h_{j}\left(q_{r}^{j}\right)
\end{array}
$$

ここに, $\boldsymbol{\mu}$ は等式制約条件, $\lambda_{i}(\geq 0), \omega_{j}(\geq 0)$ は不等式 制約条件に対するラグランジュ乗数である. 導出過程 において双対問題である上界法の制約条件も得られる ので, KKT 条件を直接解くこの解法は混合型剛塑性有 限要素法と呼ばれる．KKT 条件は以下に示すとおりで ある。

$$
\begin{aligned}
& \boldsymbol{B}^{T} \boldsymbol{\sigma}-\alpha \boldsymbol{\Gamma}_{0}-\boldsymbol{\Gamma}_{c}-\boldsymbol{D}_{d}^{T} \boldsymbol{p}-\boldsymbol{D}_{r}^{T} \boldsymbol{q}_{r}=\mathbf{0} \\
& f_{i}\left(\boldsymbol{\sigma}_{i}\right) \leq 0, \quad \forall i \\
& h_{j}\left(q_{r}^{j}\right) \leq 0, \quad \forall j \\
& 1-\boldsymbol{\mu} \cdot \boldsymbol{\Gamma}_{0}=0 \\
& \boldsymbol{D}_{d} \boldsymbol{\mu}=\mathbf{0} \\
& \boldsymbol{B} \boldsymbol{\mu}=\sum_{i=1}^{n} \lambda_{i} \frac{\partial f_{i}\left(\boldsymbol{\sigma}_{i}\right)}{\partial \boldsymbol{\sigma}_{i}}, \quad \lambda_{i} \geq 0 \\
& \boldsymbol{D}_{r} \boldsymbol{\mu}=-\sum_{j=1}^{m} \omega_{j} \frac{\partial h_{j}\left(q_{r}^{j}\right)}{\partial q_{r}^{j}}, \quad \omega_{j} \geq 0 \\
& \lambda_{i} f_{i}\left(\boldsymbol{\sigma}_{i}\right)=0, \quad \forall i \\
& \omega_{j} h_{j}\left(q_{r}^{j}\right)=0, \quad \forall j
\end{aligned}
$$

式 (13) から式 (15) は下界法に関する制約条件，式 (16) から式 (19) は上界法に関する制約条件，式 (20) と式 (21) は相補性条件である。.またラグランジュ乗数の物 理的意味は $\boldsymbol{\mu}$ は節点変位速度場, $\lambda_{i}$ や $\omega_{j}$ は塑性乗数 と解釈できる.

ここで, 式 (19) に着目する. 式 (19) の左辺は 2 点 間の伸び速度で, 式 (19) の右辺と式 (21) の相補性条 件より, $h_{j}<0$ のとき剛体， $h_{j}=0$ のとき塑性変形 である. $h_{j}=0$ を満たす $q_{j}$ は両側不等式では 2 か所 $q_{j}=q_{j \max }, q_{j}=q_{j \min }$ で, $q_{j \max }$ のとき $\frac{\partial h_{j}}{\partial q_{j}}<0$ なので 2 点間距離が縮む方向の運動, $q_{j \min }$ のとき $\frac{\partial h_{j}}{\partial q_{j}}>0$ なの で 2 点間距離が伸びる方向の運動が生じる. 片側不等 式は両側不等式の特殊なケースであると考えればよい. なお地盤拘束力 $\boldsymbol{q}_{r}$ に何も制約条件が付加されない場合, すなわち地盤補強材の引張・圧縮側の強度が十分に大き い場合は式 (17) のディリクレ境界条件と同様, 式 (19) は等式制約条件となる．換言すれば，Asaoka et al. ${ }^{8)}$ が 提案した距離不変条件と一致することを意味する.

\section{(5) 2 次錐計画問題への変形と定式化の解法}

具体的な解法は, 式 (9) を 2 次錐計画問題の形に式 変形し, 内点法搭載の汎用最適化ソルバーGurobi Optimizer $^{10), 11)}$ を使用して解いた。代表的な降伏関数のほ とんどは 2 次錐制約への形の書き換えが可能で，実際 に著者らは 2 次元問題 5 ), 3 次元問題6),7) への有効性を 確認している。例えば $c, \phi=0$ 材料を対象とし, 降伏 関数に安定化項を付加した von-Mises モデル7) を用いる 場合は降伏条件を以下のように記述することで解くべ き問題は 2 次錐計画問題となる.

$$
J_{2}^{\prime} \leq k^{2}
$$

ここに， $J_{2}^{\prime}$ は安定化項を付加した偏差応力テンソルの 第 2 不変量7) であり, $k$ は材料強度（=粘土の非排水せ 几断強度 $c$ ) である.

式 (9) 2 次錐計画問題の形で解くことで最適性条件 を満足する, 応力場 $\sigma$, 荷重係数 $\alpha$, ディリクレ反力 $\boldsymbol{p}$, 地盤拘束力 $\boldsymbol{q}_{r}$, 節点変位速度場 $\boldsymbol{\mu}$ の解が得られる

\section{(6) 空間離散化について}

本手法は混合型解法であるため, 変位速度場と応力場 両方の空間離散化を行う. 変位速度場には 3 次元 8 節点 の 1 次アイソパラメトリック要素, 応力場 $n_{\text {int }}=2 \times 2 \times 2$ のガウス積分点を用いた。

形状関数を $N$ とすると, 変位速度場 $\boldsymbol{u}$ は節点変位速 度場 $\dot{\boldsymbol{u}}_{N}$ を用いて次のように内挿できる．具体的な形 状関数の表記は，例えば，参考文献 ${ }^{12)}$ を参照されたい.

$$
\dot{u}=N \dot{u}_{N}
$$

ひずみ速度場 $\dot{\boldsymbol{\varepsilon}}$ は節点変位速度場 $\dot{\boldsymbol{u}}_{N}$ との形状関数の 偏微分 $\partial N_{I} / \partial x, \partial N_{I} / \partial y, \partial N_{I} / \partial z$ を用いて次のように 内挿される。

$$
\dot{\varepsilon}=\boldsymbol{B}_{u} \dot{\boldsymbol{u}}_{N}
$$

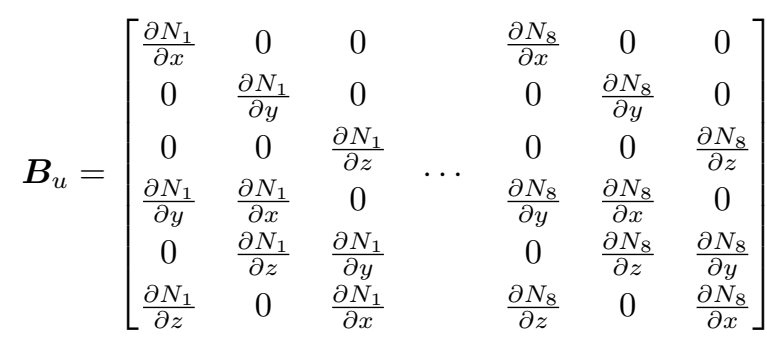

要素 $e$ における $\boldsymbol{B}_{u}$ を体積積分した量 $\int_{V_{e}} \boldsymbol{B}_{u}^{e} d V$ を積 分点 $n_{i n t}=2 \times 2 \times 2$ の数值積分で評価する. 記号 $\operatorname{det} J_{i}, w_{i}$ をそれぞれ積分点 $i$ におけるヤコビ行列式と 数值積分の重みとすれば, この数值積分は次式で表さ れる。

$$
\int_{V_{e}} \boldsymbol{B}_{u}^{e} d V=\sum_{i=1}^{n_{\text {int }}}\left[\boldsymbol{B}_{u}^{e}\right]_{i} w_{i} \operatorname{det} J_{i}
$$


表-1 計算に用いたパラメータ

\begin{tabular}{c|c}
\hline 粘着力 $c\left[\mathrm{kN} / \mathrm{m}^{2}\right]$ & 10 \\
\hline 内部摩擦角 $\phi\left[^{\circ}\right]$ & 0 \\
\hline 安定化パラメータ ${ }^{7)} \varepsilon$ & 0.01 \\
\hline
\end{tabular}

さらに式 (26) の右辺の積分点毎の行列を縦に並べた行 列を $\boldsymbol{B}_{e}$ とすれば, 行列の寸法は $(6$ ひずみ成分 $\times 8$ 積 分点 $) \times(8$ 節点 $\times 3$ 次元 $)$ であり, 次式で表される.

$$
\boldsymbol{B}_{e}=\left[\begin{array}{c}
{\left[\boldsymbol{B}_{u}^{e}\right]_{1} w_{1} \operatorname{det} J_{1}} \\
\vdots \\
{\left[\boldsymbol{B}_{u}^{e}\right]_{n_{\text {int }}} w_{n_{\text {int }}} \operatorname{det} J_{n_{\text {int }}}}
\end{array}\right]
$$

式 (6) 左辺の係数行列 $\boldsymbol{B}$ は要素ごとの $\boldsymbol{B}_{e}$ 行列を全て の要素について重㸚合わせたものとなる.

$$
\boldsymbol{B}=\sum_{e \in V} \boldsymbol{B}_{e}
$$

要素 $e$ の積分点の応力を並べて表記した応力ベクト ルを $\sigma_{e}$ とすると,

$$
\boldsymbol{\sigma}_{e}=\left(\boldsymbol{\sigma}^{1}, \cdots, \boldsymbol{\sigma}^{8}\right)
$$

ここに, $\sigma^{i}$ は要素 $e$ の積分点 $i$ における応力ベクトル であり，その成分は次式で表される.

$$
\boldsymbol{\sigma}^{i}=\left(\sigma_{x x}^{i}, \sigma_{y y}^{i}, \sigma_{z z}^{i}, \sigma_{x y}^{i}, \sigma_{y z}^{i}, \sigma_{z x}^{i}\right)
$$

この $\sigma_{e}$ を並べた応力ベクトルが式 (6) の左辺にある応 カベクトル $\sigma$ となる.

$$
\boldsymbol{\sigma}=\left(\boldsymbol{\sigma}_{1}, \cdots, \boldsymbol{\sigma}_{n e}\right)
$$

ここに, $n_{e}$ は全要素数を示す.

したがって, 式 (6) の左辺を具体的に計算することが できる.

\section{3. 数值実験}

\section{(1) 数值実験の目的}

従来の変位速度拘束条件を付加した支持力解析と補 強材の強度異方性を考慮した制約条件を付加した支持 力解析を比較し, 本手法の可能性について議論するた めに，地盤内に有限の強度を有する地盤補強材を配置 した補強土地盤上の浅い基礎の支持力解析を考える. 配 置する補強材は 1 層であり, 水平方向に配置した場合と 鉛直方向に配置した場合を考える。それぞれ CASE-A と CASE-B と称すことにする．換言すれば，これまで よりも様々な補強材のモデル化が可能であることを思 考実験によって示す.

\section{(2) 数值実験条件}

問題の対称性を考慮して解析対象領域は半断面のみ とした．数值実験に用いた 3 次元の有限要素メッシュ

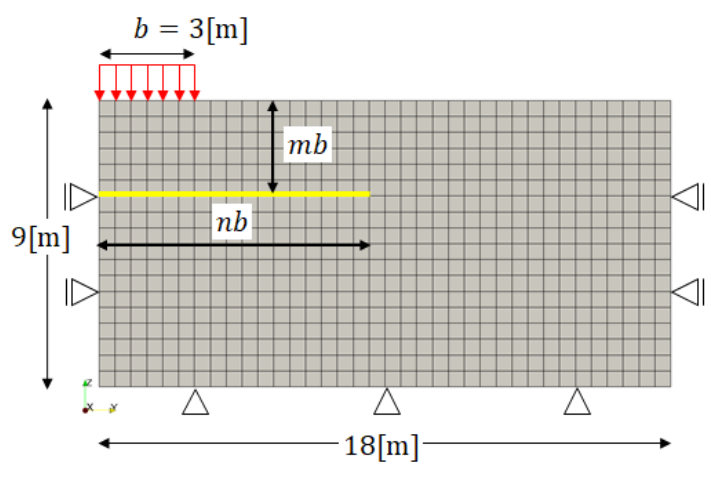

図-4-a CASE-A（水平方向に配置した場合）



図-4-b CASE-B（鉛直方向に配置した場合）

図-4 有限要素メッシュと境界条件および地盤補強材の配置 位置

（節点数：1406, 要素数 : 648）と境界条件および地盤補 強材の配置位置を図-4に示す.メッシュの奥行き方向 の長さは $d=1[\mathrm{~m}]$, 分割数は 1 , また奥行き方向を拘 束することで平面ひずみ条件 2 次元解析を行った. 荷 重条件として等方分布荷重を等価節点力に置き換えて 載荷した。また自重を無視した一様な粘性土地盤を対 象とした。降伏関数は安定化項を付加した von-Mises モ デル7）を使用し，表-1に示すように材料パラメータを 設定した。

地盤補強材の強度特性を定量的に評価するために，基 礎幅, 奥行き及び地盤強度で無次元化した無次元補強 材強度 $q^{*}$ を次式で定義する。

$$
q^{*}=\left(q_{r} / b / d\right) / c
$$

なお，本解析では補強材は奥行き $(d=0[\mathrm{~m}])$ と手前 $(d=1[\mathrm{~m}])$ に 2 本配置しているため, 式 (32)にある地 盤拘束力 $q_{r}$ は 2 本の合計值であることに注意されたい. 地盤補強材を水平方向に配置した場合は配置位置，長 さ, 強度に関するパラメータ $m, n, q^{*}$ を, 鉛直方向に配 置した場合は配置位置, 長さ, 強度に関するパラメー タ $t, s, q^{*}$ をそれぞれパラメトリックに変化させて数值 実験を行った。なお, 補強材は補強材の両端の 2 点間 を拘束するのではなく, 図-5に示すように各節点間に 


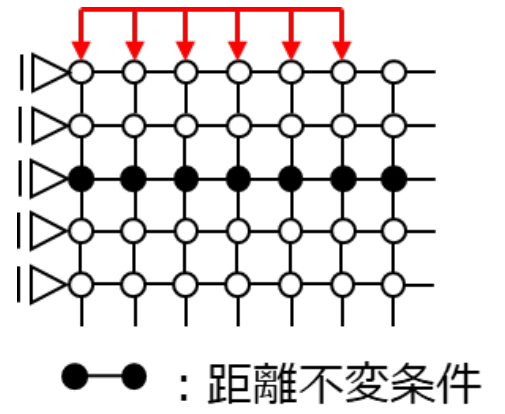

図-5 補強材のモデル化

表-2 数值実験ケースの一覧 : CASE-A（水平方向配置）

\begin{tabular}{|c|c|}
\hline \multicolumn{2}{|c|}{ 補強材強度特性 } \\
\hline $\begin{array}{c}\text { 等方的 } \\
\text { (引張‧圧縮に抵抗) }\end{array}$ & $q^{*}=\infty \quad$ （完全拘束） \\
\hline $\begin{array}{c}\text { 異方的 } \\
\text { (引張のみに抵抗) }\end{array}$ & $\begin{array}{l}q^{*}=0 \quad(\text { 無補強 }) \\
q^{*}=1,3,5,10\end{array}$ \\
\hline \multicolumn{2}{|c|}{ 補強材配置位置 · 長さ } \\
\hline 配置位置パラメータ $m$ & $\begin{array}{l}m=0 \text { (地表面 }) \\
m=0.5,1.0,1.5\end{array}$ \\
\hline 補強材長さパラメータ $n$ & $n=1,1.5,2,3,4$ \\
\hline
\end{tabular}

拘束条件を与えることでモデル化した。 また，異方的 強度特性を有する補強材（引張のみに抵抗する補強材） と等方的強度特性を有する補強材（圧縮・引張両方向 に抵抗する補強材）はそれぞれ以下のように両側不等 式制約を与えることでモデル化した.

$$
\begin{gathered}
\text { 引張のみに抵抗 }: q_{\min } \leq q_{r}^{j} \leq 0, \quad \forall j \\
\text { 圧縮・引張に抵抗 }: q_{\min } \leq q_{r}^{j} \leq q_{\max }, \quad \forall j
\end{gathered}
$$
なお, 補強材による地盤拘束力は補強材部材力と作用 反作用の関係にあることに注意されたい. また，式 (33b) において $\left|q_{\min }\right|=q_{\max }$ となるように地盤拘束力の取り 得る範囲を指定した。 実験ケースの一覧を表-2, 表-3に 示す.

無補強で得られた極限支持力は $52.38\left[\mathrm{kN} / \mathrm{m}^{2}\right]$ で, Prantdl の理論解 51.42[kN/m²] との誤差は約 $2 \%$ であ. また節点変位速度場と破壊形態は図一6に示すように理 論解と良く一致した速度場が得られた。 なお, 図-6に 示す破壊形態は破壊モードを見やすくするために速度 場に適当な時間を乗じた変位を描いたものである.

無補強地盤のケースを基準として補強土地盤では無 補強で得られた極限支持力を基準荷重に用いる.した がって, 得られる荷重係数は無補強に対する支持力の 増加割合であり, 補強効果 $\beta$ と定義する. 後述する鉛 直方向に配置した場合でも同様に基準荷重を設定した。

\begin{tabular}{|c|c|}
\hline \multicolumn{2}{|c|}{ 補強材強度特性 } \\
\hline $\begin{array}{c}\text { 等方的 } \\
\text { (引張・圧縮に抵抗) }\end{array}$ & $\begin{array}{l}q^{*}=0 \quad(\text { 無補強） } \\
q^{*}=1,3,5,10\end{array}$ \\
\hline $\begin{array}{c}\text { 異方的 } \\
\text { (引張のみに抵抗) }\end{array}$ & $\begin{array}{l}q^{*}=0 \quad(\text { 無補強） } \\
q^{*}=1,3,5,10\end{array}$ \\
\hline \multicolumn{2}{|c|}{ 補強材配置位置・長さ } \\
\hline 配置位置パラメータ $t$ & $\begin{array}{l}t t=-1 \quad \text { (基礎中央部) } \\
t=0 \quad \text { (基礎端部) } \\
t=1 \quad \text { (基礎外側 })\end{array}$ \\
\hline 補強材長さパラメータ $s$ & $\begin{array}{ll}s=1 \quad \text { (基礎幅の半分） } \\
s=2 \quad \text { (基礎幅） }\end{array}$ \\
\hline
\end{tabular}

表-3 数值実験ケースの一覧 : CASE-B（鈶直方向配置）


図-6 節点変位速度場と破壊形態（無補強）

\section{（3）数值実験：CASE-A（水平方向配置）}

等方的かつ完全拘束条件を付加した場合の数值実験 結果を図-7に示す. 図中には補強材配置位置 $m$ でのす ベり面の位置を表すパラメータ $n^{\prime}$ を赤丸で示している. なお, すべり面の位置 $n^{\prime} b$ は無補強ケースで得られた 図-6を参考に目分量で決めた. 図-7より, 補強材の引 張抵抗によって補強効果が得られ, その程度は補強材 の配置深さ, 長さによって異なることが分かる. また, 補強材を地表面を配置した場合 $(m=0)$ の補強効果 は $m=0.5$ と $m=1.0$ の間に位置していることが分か る.これは各節点間に 2 点間の拘束条件を与えている ことや地表面の地盤が斜め方向に移動する運動を補強 材が抑制するためであると考えられる.ただし, 補強 材配置深さが深い場合 $(m=1.5)$ は補強効果がほぼ得 


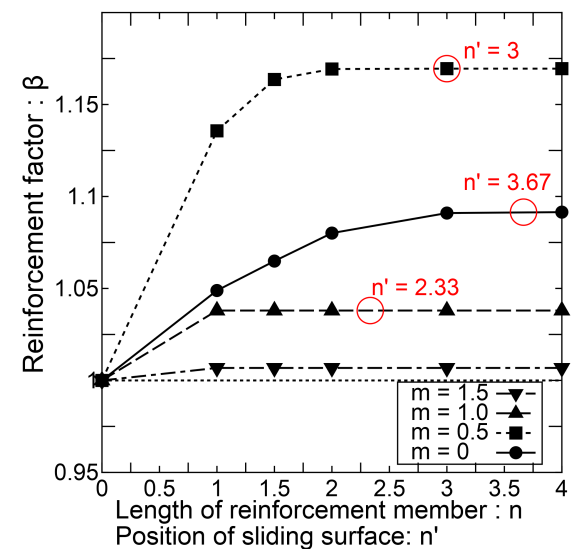

図-7 case-A : 補強効果 $\beta$ と補強材長さ $n$ の関係（補強材配置 深さ $m$ を固定，等方的・完全拘束 $\left(q^{*}=\infty\right)$ の場合 $)$

られないことが分かる。これは無補強ケースのすべり 面に影響を与えない深さに, 補強材を配置しているた

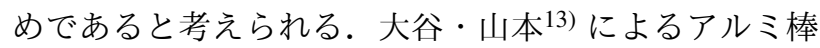
積層体地盤を用いた模型実験でも同様の傾向が報告さ れている.

また, 補強材の長さの増加に伴う補強効果について, すべり面の位置 $n^{\prime}$ よりも補強材を長くすることで充分 な補強効果が得られることが分かる. なお, $m=0.5,1.0$ において, すべり面の位置 $n^{\prime}$ より補強材の長さが短く ても補強効果が収束している様子が確認できる。これ は，後述するように補強材強度が充分に大きくなると 補強材より上の領域で局所的に地盤が破壊することや すべり面にほぼ影響を与えない深さに補強材を配置し ているため, 補強効果が収束したと考えられる.

異方的な強度特性を有するケースの数值実験結果を 図-8 から図-10に示す. 図-8より, 補強材強度によって 得られる補強効果が異なることが分かる。なお図-7 と 図-8 を比較すれば, 無次元補強材強度 $q^{*}=10$ のケー スと完全拘束条件で得られる補強効果は同様であるこ とが分かる．またこのように補強材強度を考慮するこ とで, 補強材配置深さ $m=0,0.5$ では, 補強材強度に よって補強効果がピーク（図中の矢印）となる補強材 長さが異なることが分かる.

次に図-9 と図-10より速度場について議論する。図 中の黒色の線, 黄色の線はそれぞれ補強材の塑性化した 箇所, 塑性化していない箇所を示す. 図-9より, 補強材 強度が低い場合 $\left(q^{*}=1\right)$ では, 無補強で得られた速度 場（図-6）と明膫な違いが見られない。一方，図-10よ り, 補強材強度が十分に大きい場合 $\left(q^{*}=10\right)$ は補強 材よりも上の領域で局所的な破壊が生じることが分か る.このため, 補強材強度の増加による補強効果には 上限があると考えられる．また，鉛直下向きに荷重が かかっているにもかかわらず。補強材直下の変位場が
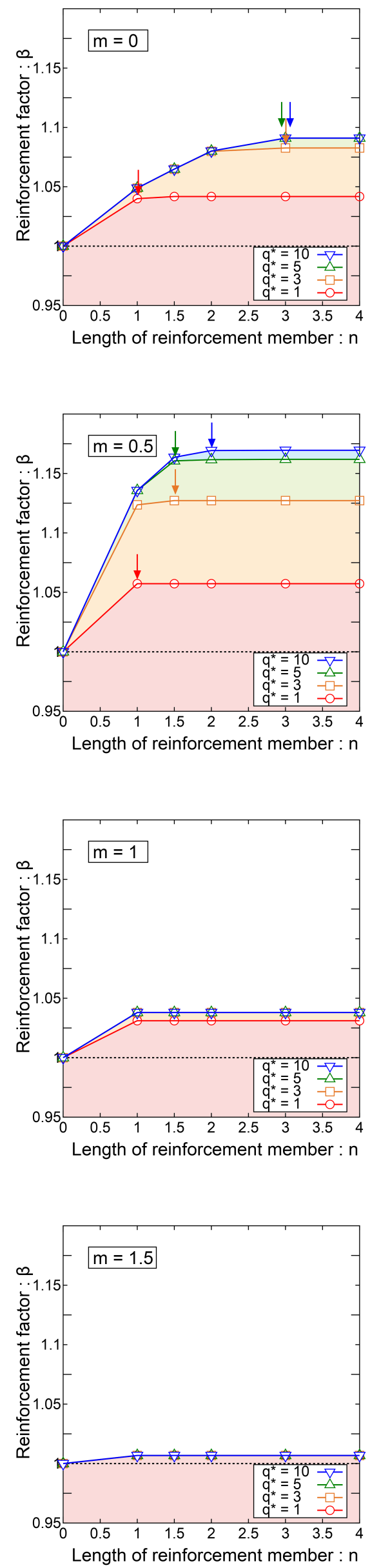

図-8 case-A : 補強効果 $\beta$ と補強材長さ $n$ の関係（補強材配 置深さ $m$ を固定，異方的） 


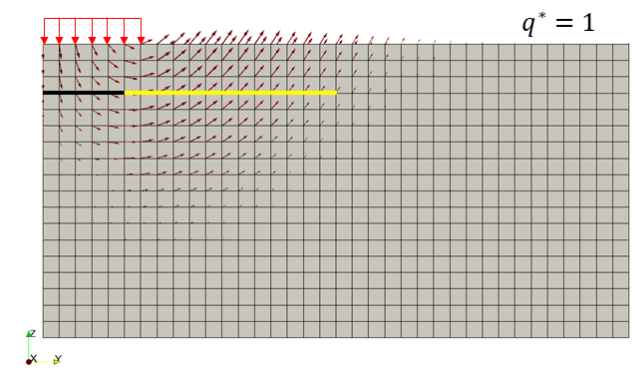

$q^{*}=1$



図-9 case-A : 節点変位速度場と破壊形態 $(m=1 / 2, n=$ $\left.3, q^{*}=1\right)$
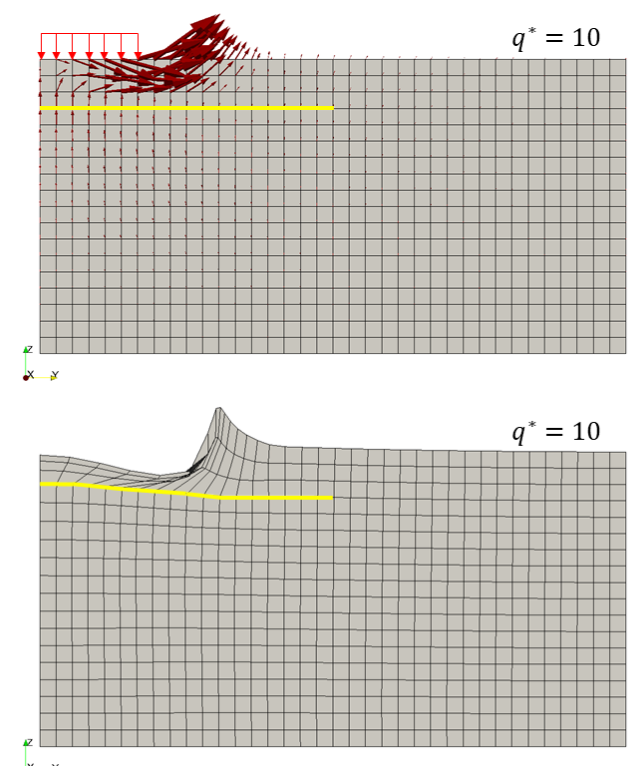

$x \times$

図-10 case-A : 節点変位速度場と破壊形態 $(m=1 / 2, n=$ $\left.3, q^{*}=10\right)$

上向き方向に現れている様子が確認できる。これは補 強材より上の土塊は水平方向に運動すること，さらに， この運動に伴って土塊直下の補強材の引き抜きが生じ ると考えられる.すなわち，この補強材の引き抜き効 果によって補強材直下の変位場が上向きに現れたと考 えられる。なお，等方的かつ完全拘束条件を付加した 場合においても同様の節点変位速度場が得られたこと を確認している.

まとめると, 従来法のように完全拘束条件を付加す ると, 補強材の長さ, 深さ位置による補強効果につい て議論ができる．さらに本手法を用いることで，補強 材強度を含めた議論をすることが可能となることが分
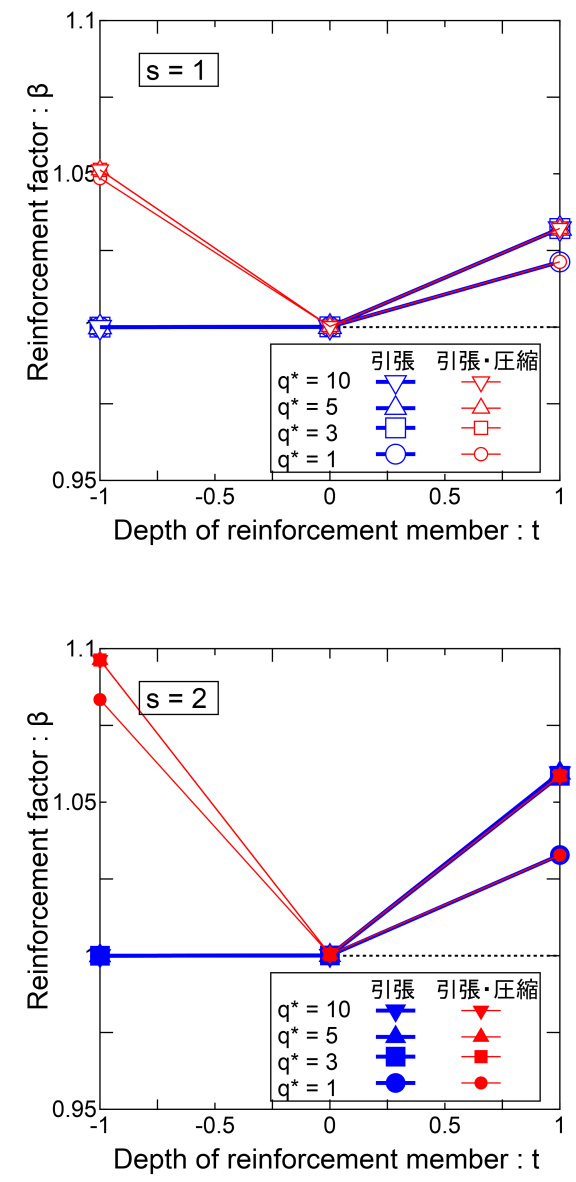

図-11 case-B : 補強率 $\alpha$ と補強材配置位置 $t$ の関係（補強材 長さ $s$ を固定)

かる.

\section{(4) 数值実験 : CASE-B（鉛直方向配置）}

補強効果 $\beta$ と補強材配置位置 $t$ の関係を図-11に示 す. 図-11より, 基礎の外側 $(t=1)$ では, どちらの補 強材においても補強効果が得られ, 強度が増加するほど その効果も増加するが, 上限がある. 基礎端部 $(t=0)$ では補強材による補強効果が見られない.これは, すべ り面と直交する位置に補強材を配置しているため, 補 強材方向の相対速度ゼロとする線形化した距離不変条 件では補強効果が得られないことを意味する。一方, 基 礎中央 $(t=-1)$ では, 引張のみ抵抗する補強材（例 えば，ジオテキスタイル）では補強効果は得られない が，引張・圧縮に抵抗する補強材（例えば，杭）では 補強効果が得られていることが分かる. また, 補強材 長さが短い場合 $(s=1)$ は補強材強度が弱い $q^{*}=1$ の ケース以外は補強効果の差はほぼ見られない. 補強材 長さが長い場合 $(s=2)$ も同様である.また全般に根入 れが深いほど補強効果が認められる.

変位場を議論するために, 破壊モードの一例を図-12, 図-13に示す.なお, 破壊形態の方が速度場の議論が明 


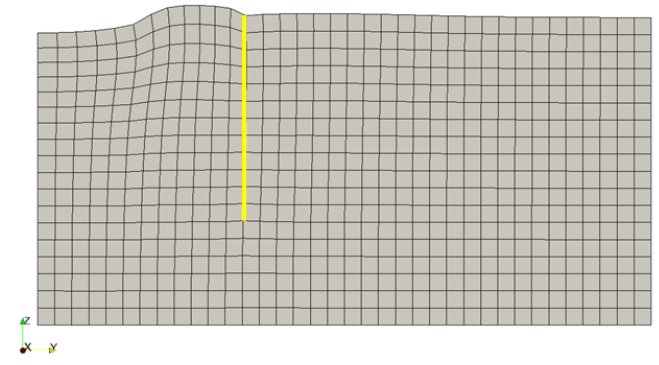

図-12-a 引張のみ抵抗する補強材

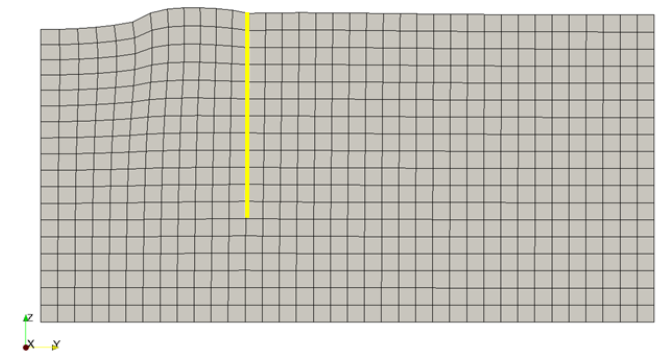

図-12-b 引張・圧縮に抵抗する補強材

図-12 case-B : 破壊形態 $\left(t=1, q^{*}=10\right)$



図-13-a 引張のみ抵抗する補強材

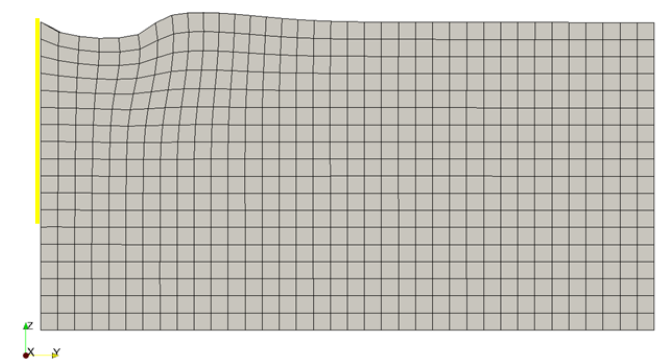

図-13-b 引張・圧縮に抵抗する補強材

図-13 case-B : 破壊形態 $\left(t=-1, q^{*}=10\right)$

快になると判断したため，前節とは異なり破壊形態の みを示す．図-12より，どちらの補強材においても，補 強材によって地盤の変形が抑制されている様子が確認 できる. 図-13より, 引張のみ抵抗する補強材では圧縮 には抵抗しないため基礎下での圧縮変形が見られる。一 方, 圧縮・引張に抵抗する補強材では, 補強材の圧縮 抵抗によって圧縮変形が抑制されている様子が確認で
きる.

以上の結果は, 地盤補強材の引張・圧縮側の強度特 性を適切に考慮できることを示しており, 本提案手法 の特徵が良く表現できていると言える.

\section{4. おわりに}

本論文では，補強材の強度異方性を考慮した剛塑性 有限要素解析を取り上げ, 線状補強材の剛塑性モデル 化と解析への実装について議論した。

既往研究では, 上界法に基づく剛塑性有限要素法に 2 節点間の距離不変条件を課すモデル化が行われていた. これを本論文では完全拘束条件と呼ぶことにした。

一方, 本研究では極限解析法の双対性に着目し, 下界 法の立場から 2 節点間の距離不変条件を再検討した. 2 節点間の距離不変条件に対応するラグランジュ乗数は, 力学的には 2 節点間に働く拘束力と解釈できる. また, この拘束力の大きさには何らかの制約条件が課されな いため, 2 点間の完全拘束条件は補強材強度が十分大き い（無限大）場合に対応していることが分かった。より 一般的な状況，すなわち補強材の引張り強度や圧縮強 度に限界がある場合は，下界法に基づく剛塑性有限要 素法の定式化に，拘束力に上限值や下限值を設定した 不等式制約条件を追加することで容易に表現できるこ とが確認された。ここに引張り強度と圧縮強度は異なっ ても構わないので, 補強材の強度異方性も表現できる. このように，上界法と下界法が互いに双対関係にある ことを考慮し，下界法から上界法で提案されたモデル 化を再検討したことは本研究の着眼点であり, さらに 下界法に基づいて地盤拘束力に不等式制約を課した剛 塑性有限要素法の定式化を行ったことは新規性に富ん でいると言える.

提案手法の有効性を示すため，これを実装した混合 型剛塑性有限要素解析コードを開発し, 飽和粘性土地 盤に線状補強材を水平方向あるいは鉛直方向に配した 補強土地盤上の浅い基礎の 2 次元支持力問題を取り上 げ，簡単な数值実験を行った。

地盤補強材を水平に配したケースでは，補強材には 引張り力のみが作用すること, 無補強ケースのすべり 面を横切る位置に補強材を配する必要があることを確 認した。また，2つの極端なケース，すなわち無補強 と完全拘束条件の補強以外に, 補強材強度が有限とな る中間的な条件についても, その補強効果を求めるこ とが可能となった。

線状補強材を鉛直に配するケースでは，基礎中央部 に線状補強材を配する場合, 引張・圧縮両側に抵抗す る補強材（杭など）であれば支持力改善が期待できる が，引張のみに抵抗する補強材（ジオテキスタイルな 
ど）であれば支持力改善には寄与しないことが確認さ れた。 また基礎端部に補強材を配する場合は，すべり 面と補強材がちょうど直交する位置に補強材が配置さ れ, 補強材方向の相対速度をゼロとする線形化した距 離不変条件では変形拘束効果が表れないため, 補強効 果が期待できないこと.さらに, 基礎の外側に補強材 を配する場合は, 補強材には引張り力のみが作用する ため, 引張のみに抵抗する補強材であっても補強効果 が期待できることが確認された。

またいずれのケースにおいても, 引張・圧縮のみに 抵抗する線状補強材では, 補強材強度が十分に大きな 場合でも補強効果には限度があり, 本論文の手法を用 いれば, 効果的な補強材強度を評価できる.

上記をまとめると, 本提案手法は補強材配置位置, 補 強材長さ, 補強材強度といった実務設計で必要となる 情報を簡単に評価可能であり, 実務設計への応用も期 待できると思われる。

最後に, 本提案手法によって補強材の強度特性を考 虑した補強材のモデル化が可能となった。一方, 本モ デル化は, ジオテキスタイルや杭のように補強材と地 盤の摩擦による補強効果は考慮していない。実際の補 強土では摩擦効果を無視することはできないため, 今 後は摩擦を考慮したモデル化を検討していきたい。

\section{参考文献}

1) Tamura, T., Kobayashi, S. \& Sumi, Y.: Limit analysis of soil structure by rigid plastic finite element method, Soils and Foundations, Vol. 24, No.1, pp.34-42, 1984.

2) Tamura, T., Kobayashi, S. \& Sumi, Y.: Rigid plastic finite element method for frictional material, Soils and Foundations, Vol. 27, No.3, pp.1-12, 1987.
3) 小林俊一: 主双対内点法に基づく混合型剛塑性有限要素 法の開発, 応用力学論文集, 土木学会, Vol. 6, pp.95-106, 2003.

4) Kobayashi, S.: Hybrid type rigid plastic finite element analysis for bearing capacity characteristics of surface uniform loading, Soils and Foundations, Vol. 45, No. 2, pp. 17-27, 2005.

5) 西藤潤, 春日井健太, 小林俊一: 二次錐計画問題の双対問 題を用いた極限解析の解法, 第 19 回応用力学シンポジウ ム, 土木学会, CD-ROM, 2016.

6) 山栗祐樹, 小林俊一, 西藤潤, 松本樹典: 修正カムクレイモ デルを破壊規準に用いた剛塑性有限要素法について, 土 木学会論文集 A2 (応用力学), Vol.73, No.2, I_333-I_342, 2017.

7) 山栗祐樹, 小林俊一, 西藤潤, 松本樹典: 2 次錐計画に基づ < $\phi$ 材料の数值塑性解析に関する考察, 土木学会論文集 A2 (応用力学), Vol. 74, No. 2, I_191-I_202, 2018.

8) Asaoka, A., Kodaka, T. \& Pokharel, G.:Stability of reinforced soil structures using rigid plastic finite element method, Soils and Fandations, Vol. 34, No.1, pp.107-118, 1994.

9) Kodaka, T., Asaoka, A. \& Pokharel, G.:Model tests and theoretical analysis of reinforced soil slopes with facing panels, Soils and Foundations, Vol. 35, No. 1, pp. 133-145, 1995.

10) 久保幹雄, J.P. ペドロソ, 村松正和, A.レイス: あたらしい 数理最適化-Python 言語と Gurobi で解く-, 近代科学社, 2012.

11) Gurobi Optimizer: http://www.gurobi.com/, 2019 年 2 月 7 日アクセス。

12）熟津久一郎, 宮本博, 山田嘉昭, 山本義之, 川井忠彦: 有限 要素法ハンドブック 基礎編, 培風館, 1981.

13) 大谷順, 山本健太郎: 補強土基礎地盤における局所变形 の解明, ジオシンセティックスシンポジウム発表論文集, Vol. 10, pp. 134-141, 1995.

(Received July 19, 2019)

(Accepted December 10, 2019)

\title{
MODELING OF A LINEAR SOIL-REINFORCEMENT MEMBER AND ITS IMPLEMENTATION INTO A RIGID-PLASTIC FINITE ELEMENT METHOD
}

\author{
Yuki YAMAKURI, Shun-ichi KOBAYASHI, Jun SAITO and Tatsunori MATSUMOTO
}

A rigid plastic finite element method is a numerical tool based on the limit theorem to solve directly the failure mode and its ultimate capacity, such as bearing capacity of shallow foundations. To model a soil-reinforcement effect by linear reinforcement members, the introduction of a constant length condition between two nodes can be found in the literature. In this article, the authors re-investigate this constant length condition and extend it for more general cases. Based on Lagrangian duality theory, a Lagrangian multiplier for this constant length condition can be interpreted as a constraint force between the two nodes. The authors introduce an additional inequality constraint on this Lagrangian multiplier in a hybrid formulation of a rigid plastic finite element method to express finite and anisotropic strength properties of linear reinforcement members. Some numerical examples are presented to demonstrate the ability of the proposed method. 